\title{
KLIMATOLOGI BADAI PETIR DI WILAYAH JAKARTA DAN SEKITARNYA BERDASARKAN OBSERVASI SYNOP TAHUN 2000-2012
}

\author{
Thunderstorm Climatology in the Jakarta Area and Its Surroundings \\ Based on Synoptic Observations from 2000-2012.
}

\author{
Ardhi Adhary Arbain ${ }^{1)^{*}}$ \\ 1) Balai Besar Teknologi Modifikasi Cuaca - Badan Pengkajian dan Penerapan Teknologi, Gedung Ir. \\ Mohammad Soebagio, GEOSTECH (820), Kawasan PUSPIPTEK, Serpong, Tangerang Selatan \\ 1) Atmosphere and Ocean Research Institute (AORI), The University of Tokyo, Japan \\ *E-mail : ardhi.adhary@bppt.go.id
}

\begin{abstract}
Intisari
Klimatologi badai petir (TS) dianalisis dengan memanfaatkan pengamatan SYNOP per 3-jam dari 8 stasiun cuaca BMKG yang berada di wilayah Jakarta dan sekitarnya selama periode tahun 20002012. Frekuensi kejadian TS pada tiap lokasi dihitung berdasarkan perbandingan antara jumlah laporan TS pada data SYNOP dengan jumlah total observasi yang dilakukan oleh stasiun yang bersangkutan. Hasil pengolahan data menunjukkan bahwa TS memiliki dua pola klimatologi yang dominan dan paling sering terjadi pada periode sebelum dan sesudah musim hujan, terutama pada bulan November dan April. Hasil analisis juga menunjukkan bahwa TS sangat bergantung pada topografi dari lokasi yang bersangkutan, yang mengindikasikan pengaruh kuat dari siklus harian akibat konveksi kuat dan pola angin darat-laut di wilayah Jakarta dan sekitarnya. Pada beberapa lokasi yang berdekatan dengan Teluk Jakarta, periode puncak kejadian TS juga terjadi pada puncak musim hujan akibat pengaruh dari monsun barat laut dan seruak dingin yang datang dari Laut Tiongkok Selatan. Variabilitas iklim global seperti ENSO (El Nino Southern Oscillation) dan MJO (Madden-Julian Oscillation) turut memberikan pengaruh signifikan terhadap frekuensi TS. Hasil analisis menunjukkan bahwa frekuensi TS mengalami peningkatan pada periode La Nina kuat, serta pada periode sebelum dan sesudah MJO melintasi Indonesia bagian barat.
\end{abstract}

Kata Kunci : Badai Petir, Klimatologi, Siklus Harian, ENSO, MJO.

\begin{abstract}
Thunderstorm (TS) climatology was analyzed by utilizing 3-hourly SYNOP observation of 8 BMKG's weather stations in Jakarta capital and surrounding area during the period of 2000-2012. The frequency of TS occurrences at each location was calculated based on the ratio of TS reports to the total number of SYNOP observations conducted by the stations. The results show that the TS has two dominant climatological patterns in which most cases, the peak periods both preced and succeed the rainy season, especially in November and April. The results also imply that TS occurences are heavily influenced by the topography at each location, which indicate the great dependency of TS to the diurnal cycle generated by strong convective activity and land-sea breeze circulation over Jakarta and surronding regions. On the other hand, the peak period of TS at some locations close to Jakarta Bay, occurs simultaneously with the peak of rainy season by the influence of north-westerly monsoon and cold surge coming from the South China Sea. Global climate variabilities such as ENSO (EI Nino Southern Oscillation) and MJO (Madden-Julian Oscillation) also significantly contribute to the anomaly of TS frequency. The results show an enhancement of TS frequency during the period of strong La Nina, as well as the period before and after MJO passes the western part of Indonesia.
\end{abstract}

Keywords : Thunderstorm, Climatology, Diurnal Cycle, ENSO, MJO.

\section{PENDAHULUAN}

Badai petir atau thunderstorm (selanjutnya akan disebut TS), merupakan salah satu fenomena cuaca yang paling umum terjadi pada wilayah tropis maupun sub-tropis di seluruh dunia. Karakteristik utama TS adalah keberadaan kilat dan petir yang dibawa oleh tipe awan
Cumulonimbus $(\mathrm{Cb})$, serta umumnya terjadi bersama dengan angin kencang dan hujan lebat, bahkan tak jarang menimbulkan hujan es (hail) serta puting beliung (tornado). TS umumnya terjadi akibat proses upward yang kuat dari udara hangat dan lembap yang dibangkitkan oleh konveksi di permukaan bumi. Udara lembap yang naik kemudian mengalami pendinginan dan 
kondensasi, serta membentuk awan $\mathrm{Cb}$ yang dapat menjulang hingga ketinggian lebih dari 20 $\mathrm{km}$. TS kerap kali menimbulkan kerusakan yang parah pada bangunan, memutuskan aliran listrik bahkan tak jarang memakan korban jiwa pada daerah-daerah yang dilaluinya. Petir yang ditimbulkan oleh TS juga diketahui sebagai salah satu sumber gas-gas $\mathrm{NO}_{\mathrm{x}}$, yang dapat memberikan pengaruh pada lapisan ozon di atmosfer, sehingga TS secara tak langsung ikut mempengaruhi iklim global (Schumann \& Huntrieser, 2007).

Benua Maritim Indonesia (BMI) adalah wilayah tropis dengan distribusi kepulauan yang unik, topografi yang kompleks, serta merupakan salah satu daerah dengan suhu muka laut terhangat di dunia, sehingga sering disebut sebagai "boiler box" of the tropics (Ramage, 1968). Dengan karakteristik yang sedemikian rupa, Indonesia termasuk wilayah tropis yang memiliki curah hujan dan aktivitas TS tertinggi di dunia (Keenan et al., 2000; Christian et al., 2003; Neale \& Slingo, 2003; Takayabu, 2006). Guiness Book of World Records bahkan sempat mencatatkan daerah Bogor sebagai tempat dengan aktivitas TS terbanyak, dengan jumlah 322 hari TS dalam setahun. Lebih dari itu, TS di Indonesia berpotensi memicu bencana lain yang seringkali menimbulkan kerugian yang lebih besar dibandingkan kerusakan yang dibawa oleh TS itu sendiri, misalnya peristiwa bobolnya tanggul Situ Gintung, Ciputat pada bulan Maret 2009 atau kejadian tanah longsor di Cililin, Bandung Barat pada bulan Maret 2013, belum lagi bencana-bencana serupa yang telah terjadi sebelumnya di berbagai lokasi di Indonesia. Hal ini menunjukkan bahwa studi komprehensif, terutama tentang karakteristik TS secara klimatologis, sangat diperlukan dalam mengembangkan sistem peringatan dini bencana hidrometeorologi di Indonesia, terutama untuk wilayah-wilayah strategis, seperti Daerah Khusus Ibukota Jakarta dan sekitarnya.

Karakteristik TS secara klimatologis umumnya dapat dianalisis dengan memanfaatkan berbagai data observasi, baik insitu, maupun penginderaan jauh. Observasi insitu seperti World Wide Lightning Location Network (WWLLN [Rodger et al., 2006]) memberikan hasil pengamatan dengan kualitas dan resolusi temporal tinggi, namun terkendala oleh terbatasnya distribusi jaringan pengamatan, termasuk di wilayah Indonesia. Di sisi lain, pengamatan penginderaan jauh seperti dengan Optical Transient Detector (OTD) satelit Microlab1 atau Lightning Imaging Sensor (LIS) dari satelit Tropical Rainfall Measurement Mission (TRMM) umumnya mampu memberikan informasi distribusi spasial TS secara global, namun terkendala oleh sampling data yang rendah secara temporal (Virts et al., 2013). Ketersediaan format data yang kurang baku juga merupakan salah satu faktor mengapa penelitian tentang TS, khususnya di Indonesia, tidak terlalu berkembang bila dibandingkan dengan studi hidrometeorologi lainnya.

Studi ini menawarkan alternatif baru dalam mengulas karakteristik TS di Indonesia dari sisi klimatologis, dengan menggunakan data observasi yang memiliki format baku yang relatif mudah diolah serta dapat diperoleh secara bebas dan gratis: SYNOP. Sebagai langkah awal, studi klimatologi TS difokuskan pada wilayah Jakarta dan sekitarnya, pada periode tahun 2000-2012. Studi ini diharapkan dapat diaplikasikan pada daerah-daerah lain di seluruh Indonesia serta mampu mendorong pengembangan teknik pengolahan data non-konvensional untuk berbagai penelitian tentang iklim dan cuaca.

\section{METODE}

Data utama yang digunakan dalam penelitian ini adalah observasi SYNOP (Surface Synoptic Observations), atau yang biasa disebut FM 12-IX oleh World Meteorological Organization (WMO). SYNOP merupakan data yang terdiri dari kode numerik yang digunakan untuk melaporkan pengamatan cuaca oleh stasiun darat dan tidak bergerak, baik yang berawak maupun nirawak di seluruh dunia. Data SYNOP mengandung beberapa kelompok kode yang menjelaskan kondisi umum cuaca seperti suhu, tekanan udara, kelembapan relatif, arah dan kecepatan angin, hingga informasi cuaca spesifik seperti jarak pandang, tutupan awan dan kondisi cuaca, baik pada saat pengamatan, maupun pada pengamatan sebelumnya.

Ditinjau dari waktu pelaporannya, terdapat dua format observasi SYNOP yang umum digunakan, yaitu format lengkap (complete form) dan format pendek (shortened form). Observasi SYNOP dengan format lengkap dilaporkan setiap 6 jam (pada 00, 06, 12 dan 18 UTC), sehingga sering disebut juga dengan format 6-jam. Di sisi lain, SYNOP dengan format pendek dilaporkan setiap 3 jam (pada 00, 03, 06, 09, 12, 15, 18 dan 21 UTC), sehingga biasa disebut format 3-jam. Dari sisi struktur data, observasi SYNOP umumnya dilaporkan dalam bentuk teks ASCII (American Standard Code for Information Interchange) yang dapat diunduh secara gratis pada berbagai situs pengamatan cuaca online di internet.

Pada studi ini, data observasi SYNOP yang digunakan memiliki format pendek (3-jam) yang dilaporkan oleh 8 dari total 13 stasiun cuaca Badan Meteorologi Klimatologi dan Geofisika (BMKG) yang berada di sekitar Jakarta selama periode tahun 2000-2012 (Gambar 1). Untuk analisis klimatologi, stasiun cuaca dipilih berdasarkan ketersediaan data SYNOP, dimana hanya stasiun yang memiliki periode pengamatan SYNOP paling sedikit 10 tahun yang akan digunakan dalam perhitungan. Dari 8 stasiun yang datanya dianalisis, hanya 2 stasiun 
(Tanjung Priok dan Jakarta Observatory) yang memiliki rekaman data SYNOP selama 11 tahun, sedangkan sisanya memiliki rekaman lengkap hingga 13 tahun.

Informasi TS yang digunakan untuk studi ini diperoleh dari kelompok kode identifikasi $7 w w W_{1} W_{2}$ dari observasi SYNOP. Keberadaan observasi SYNOP diperoleh dari manual WMONo.306 tentang kode alfanumerik internasional dan Federal Meteorological Handbook (FMH) No.2.

Secara sederhana, frekuensi kejadian bulanan TS (selanjutnya akan disebut sebagai $\mathrm{MP}_{\mathrm{TS}}$ ) didefinisikan sebagai jumlah hari dengan paling sedikit satu kali laporan TS (TSD) per total hari pada bulan yang bersangkutan (TotD), atau dapat dituliskan sebagai:

$$
M P_{T S}=\frac{\sum T S_{D}}{T_{o t}} \times 100 \%
$$

$\mathrm{MP}_{\mathrm{TS}}$ akan memiliki nilai maksimum $\left(\mathrm{MP}_{\mathrm{TS}}=1\right.$ atau $\left.\mathrm{MP}_{\mathrm{TS}}=100 \%\right)$ apabila seluruh hari pada bulan pengamatan memiliki setidaknya satu kali TS yang teramati, atau dengan kata lain, TS terjadi setiap hari pada bulan tersebut. Sebaliknya, $\mathrm{MP}_{\mathrm{TS}}$ akan bernilai minimum $\left(\mathrm{MP}_{\mathrm{TS}}=0\right.$ atau $\left.\mathrm{MP}_{\mathrm{TS}}=0 \%\right)$ apabila TS tidak terjadi sama sekali pada bulan tersebut. Nilai $\mathrm{MP}_{\mathrm{TS}}$ tersebut kemudian dibagi dengan total bulan pengamatan yang sama $\left(\operatorname{Tot}_{\mathrm{M}}\right)$ untuk memperoleh rata-rata klimatologis dari TS $\left(\mathrm{CliMP}_{\mathrm{TS}}\right)$. Sehingga:

$$
\operatorname{CliMP}_{T S}=\frac{\sum M P_{T S}}{\operatorname{Tot}_{M}}
$$

Metode serupa juga diterapkan untuk analisis harian TS, di mana frekuensi TS per jam dihitung berdasarkan jumlah total laporan TS
TS didefinisikan dengan adanya baris data yang mengandung kode informasi TS, dengan presipitasi maupun tanpa presipitasi, baik pada saat pengamatan (kode $W_{1} W_{2}$ ) maupun pada pengamatan sebelumnya (kode $w w, 3$ jam sebelumnya). Deskripsi lengkap tentang kode

pada jam tersebut dibandingkan dengan jumlah total pengamatan TS pada jam yang sama.

Karena kejadian TS di wilayah tropis sangat berhubungan erat dengan hujan konvektif, maka studi ini juga menggunakan data curah hujan dari produk Global Satellite Mapping of Precipitation Microwave Radiometer (GSMaP MWR) dan GSMaP Reanalysis version 5 (GSMaP_MVK ver. 5) dari Japan Aerospace Exploration Agency (JAXA), dengan resolusi spasial $0.25^{\circ}$ untuk GSMaP_MWR dan $0.1^{\circ}$ untuk GSMaP MVK. Informasi curah hujan bulanan GSMaP_MWR digunakan sebagai data pembanding untuk analisis variabilitas musiman (seasonal variability), sedangkan data per jam GSMaP_MWK digunakan untuk analisis siklus harian (diurnal cycle) TS. Hal ini dilakukan dengan asumsi bahwa kejadian TS yang teramati oleh stasiun cuaca dapat mencakup daerah yang cukup luas $(1-30 \mathrm{~km})$, sehingga penggunaan data spasial lebih merepresentasikan hujan konvektif di sekitar wilayah stasiun cuaca. Informasi curah hujan bulanan dari data spasial dihitung dari rata-rata bulanan curah hujan pada piksel terdekat dengan lokasi stasiun cuaca.

Data pembanding lain, seperti Real-time Multivariate MJO Index (RMM) dan indeks NINO3.4 dari Bureau of Meteorologi (BOM) Australia, juga digunakan untuk mengetahui hubungan antara frekuensi TS dengan variabilitas iklim global seperti Madden-Julian Oscillation (MJO) dan El-Nino Southern Oscillation (ENSO).

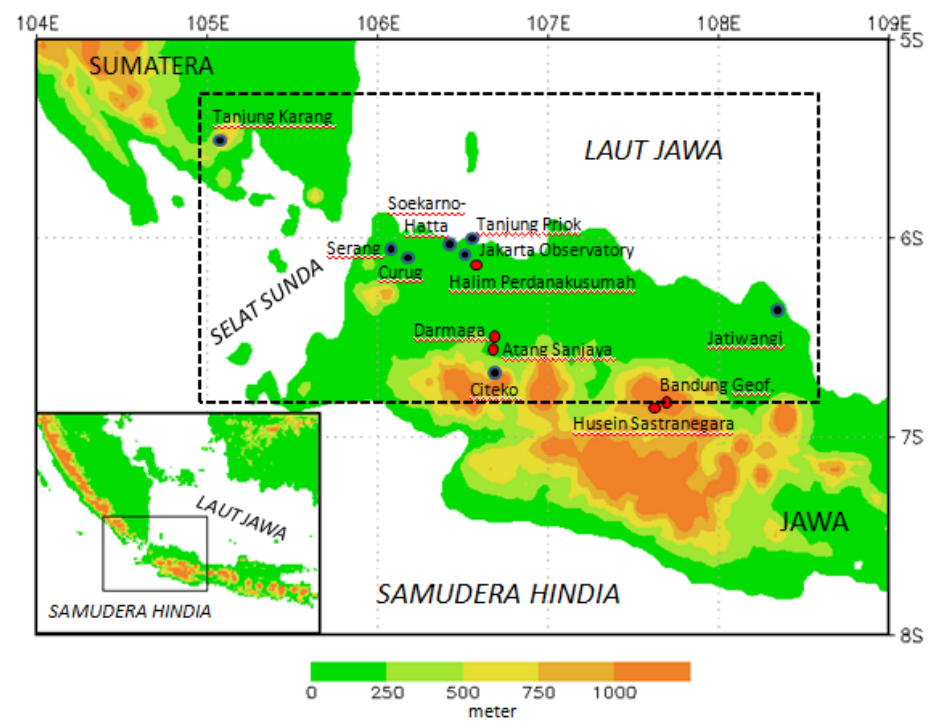

Gambar 1. Lokasi stasiun cuaca yang berada di wilayah Jakarta dan sekitarnya. (Stasiun dengan ketersediaan data SYNOP lebih dari 10 tahun disimbolkan dengan lingkaran biru, sedangkan stasiun dengan ketersediaan data SYNOP kurang dari 10 tahun disimbolkan dengan lingkaran merah. Kotak dengan garis hitam putus-putus menunjukkan wilayah analisis curah hujan wilayah dengan data GSMaP) 


\section{HASIL DAN PEMBAHASAN}

\subsection{Variabilitas Musiman TS}
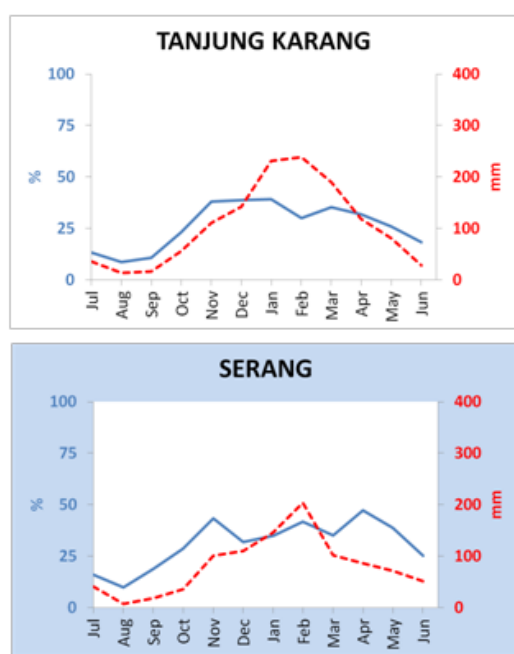
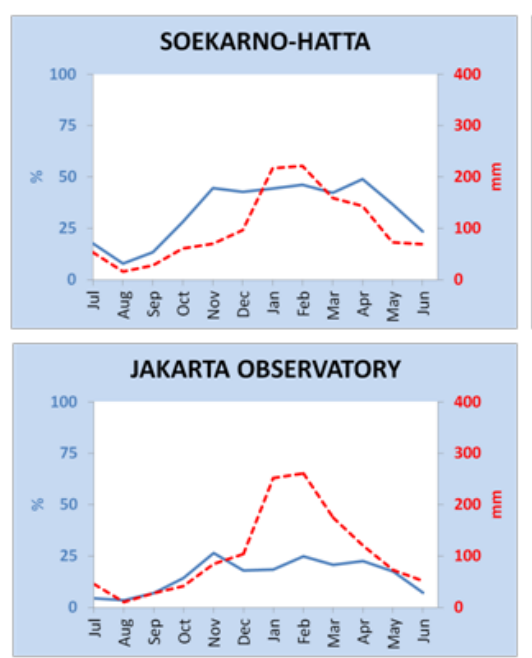

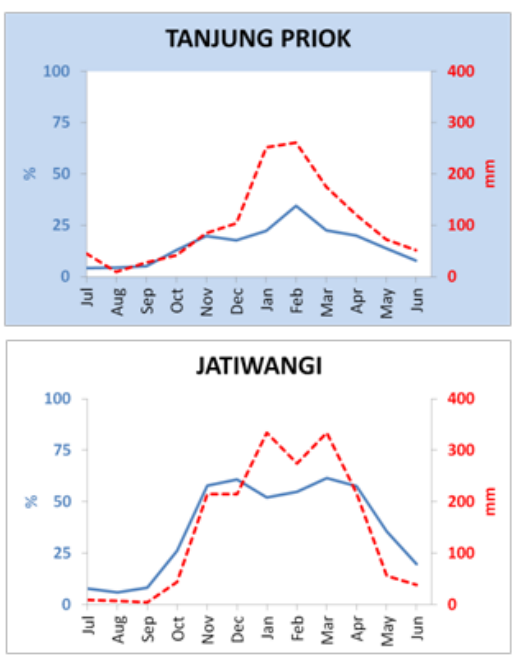

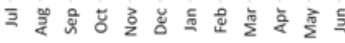

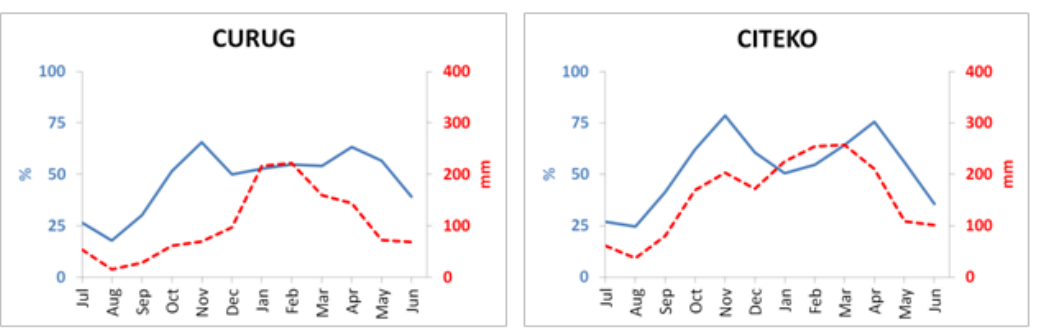

Gambar 2. Grafik klimatologi bulanan kejadian TS (garis biru) dan curah hujan bulanan (garis putusputus merah) untuk setiap stasiun cuaca di wilayah Jakarta dan sekitarnya. (Grafik dengan latar belakang biru menunjukkan lokasi stasiun yang terdekat dengan Teluk Jakarta)

Gambar 2 menunjukkan grafik klimatologi bulanan kejadian TS yang teramati oleh setiap stasiun cuaca di wilayah Jakarta dan sekitarnya (garis solid biru), dibandingkan dengan klimatologi bulanan curah hujan pada stasiun yang sama (garis putus-putus merah).

Terlihat bahwa terdapat dua pola klimatologi dominan, baik untuk kejadian TS maupun curah hujan. Kebanyakan lokasi stasiun memiliki dua periode puncak kejadian TS dalam setahun, umumnya pada bulan April dan November. Hanya lokasi-lokasi yang terdekat dengan Teluk Jakarta (kecuali Tanjung Priok) yang memiliki tiga periode puncak kejadian TS, yaitu pada bulan Februari, April dan November. Citeko merupakan wilayah yang memiliki kejadian TS terbanyak, yaitu $78,46 \%$ dan $75,64 \%$ dalam sebulan, masing-masing pada bulan November dan April. Dengan kata lain, rata-rata terjadi 22-23 hari kejadian TS di Citeko pada bulan-bulan tersebut. Daerah lain yang memiliki kejadian TS terbanyak adalah Jatiwangi dan Curug. Di sisi lain, hampir semua lokasi memiliki satu puncak curah hujan dalam setahun, yaitu pada bulan Februari. Dalam hal ini, hanya dua stasiun yang lokasinya paling timur, yaitu Citeko dan Jatiwangi, yang memiliki dua puncak curah hujan, yang terjadi selain pada bulan Februari. Daerah yang memiliki rata-rata curah hujan tertinggi adalah Jatiwangi pada bulan Maret, yaitu sebesar 333,62 mm, diikuti oleh Jakarta dan Citeko, masing-masing pada bulan Februari dan Maret.

Hal menarik yang perlu diperhatikan adalah puncak kejadian TS yang kebanyakan memiliki periode berbeda dengan puncak musim hujan. Dengan asumsi bahwa musim hujan di wilayah barat pulau Jawa dan wilayah selatan pulau Sumatera terjadi pada periode boreal winter (Desember-Januari-Februari atau DJF), maka Gambar 2 menunjukkan bahwa TS paling sering terjadi sesaat sebelum dan sesudah musim hujan, yaitu pada bulan November dan April. Pengecualian diberikan pada lokasi-lokasi di sekitar Teluk Jakarta dan Laut Jawa yang memiliki puncak kejadian TS yang relatif bersamaan dengan puncak musim hujan pada bulan Februari atau Maret. Gambar 2 juga menunjukkan bahwa daerah yang lokasinya lebih jauh dari pantai (inland) atau daerah yang memiliki elevasi lebih tinggi seperti Citeko, memiliki kejadian TS relatif lebih banyak dibandingkan dengan daerah pantai (coastal) atau daerah dengan elevasi rendah, misalnya Jakarta. Dalam hal ini, pengecualian diberikan pada wilayah Jatiwangi (Cirebon) yang memiliki kejadian TS cukup banyak walaupun berada di daerah pantai.

Adanya jeda waktu antara periode puncak TS dan curah hujan di banyak lokasi pengamatan 


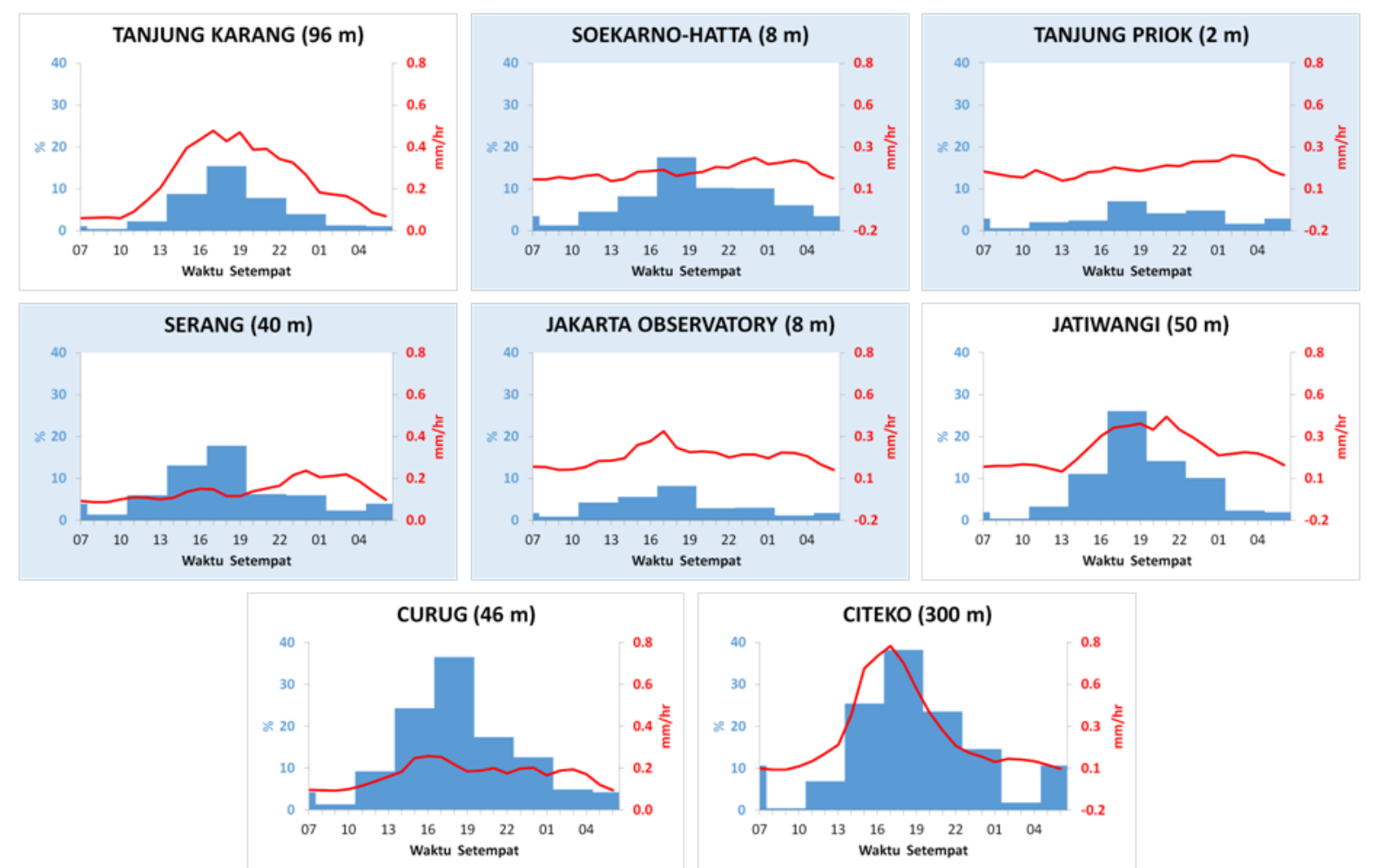

Gambar 3. Grafik klimatologi harian kejadian TS (diagram batang biru) dan curah hujan (diagram garis merah) untuk setiap stasiun cuaca di wilayah Jakarta dan sekitarnya. Elevasi tiap stasiun (dari permukaan laut) ditampilkan pada bagian judul grafik (dalam kurung). Grafik dengan latar belakang biru menunjukkan lokasi stasiun yang terdekat dengan Teluk Jakarta.

memberikan indikasi bahwa kejadian TS di wilayah-wilayah tersebut tidak hanya dipengaruhi oleh monsun barat laut, namun juga oleh faktor topografi lokal dari lokasi yang bersangkutan. Periode puncak TS yang terjadi bersamaan dengan puncak musim hujan pada bulan Februari atau Maret, yang hanya terjadi pada lokasi-lokasi yang berdekatan dengan Teluk Jakarta dan Laut Jawa, diduga merupakan akibat dari Cold Surge (CS) yang kerap terjadi mulai dari wilayah Laut Tiongkok Selatan hingga Laut Jawa pada periode boreal winter (Chang et al., 2005; Wu et al., 2007, 2013; Hattori et al., 2011). Di sisi lain, daerah inland atau daerah yang lokasinya cukup jauh dari Laut Jawa, pengaruh CS terhadap kejadian TS terlihat kurang signifikan. Faktor topografi lokal yang merupakan salah unsur utama dari siklus harian (diurnal cycle) di BMI diduga merupakan pemicu utama kejadian TS di lokasi-lokasi tersebut (Mori et al., 2004; Takayabu, 2006; Wu et al., 2007; Virts et al., 2013).

\subsection{Siklus Harian TS}

Gambar 3 menunjukkan grafik klimatologi kejadian TS per tiga jam (diagram batang biru) dan curah hujan tiap jam (garis merah) untuk tiap lokasi stasiun cuaca. Terlihat jelas bahwa kejadian TS paling sering terjadi antara pukul 17-19 waktu setempat (Waktu Indonesia Barat, WIB) di seluruh lokasi. Selain itu, terlihat pula bahwa lokasi-lokasi yang berada lebih jauh dari daerah coastal (kecuali Jatiwangi) umumnya memiliki frekuensi kejadian TS lebih banyak. Hal ini semakin memperkuat dugaan bahwa fenomena TS di wilayah Jakarta dan sekitarnya dipicu oleh siklus harian. Kejadian TS diduga mulai terjadi ketika awan Cumulonimbus (Cb) yang tumbuh di wilayah inland mencapai fase matang (mature) pada sore menjelang malam hari, dan mulai bergerak menuju daerah coastal akibat pengaruh angin darat (land breeze), seperti yang dijelaskan oleh berbagai studi tentang siklus harian di Indonesia (Renggono et al., 2001; Sakurai et al., 2005, 2009; Mori et al., 2011). Frekuensi TS yang semakin berkurang di daerah pantai kemungkinan disebabkan oleh awan $\mathrm{Cb}$ yang makin meluruh seiring dengan pergerakannya dari wilayah inland ke wilayah coastal. Kejadian TS paling sering terjadi di wilayah Citeko pada pukul 17-19 WIB, dengan frekuensi laporan rata-rata sebanyak 38,24\% dalam kurun waktu antara tahun 2000-2012.

Gambar 3 juga menunjukkan bahwa curah hujan maksimum umumnya tidak terjadi bersamaan dengan puncak kejadian TS. Menarik untuk dicermati bahwa pada daerah - daerah inland seperti Citeko atau Curug, curah hujan maksimum cenderung mendahului puncak kejadian TS, dengan jeda waktu berkisar antara 1 sampai 3 jam. Di wilayah coastal (Tanjung Priok, Jatiwangi dan Serang), curah hujan maksimum cenderung lebih lambat terjadi dibandingkan puncak periode TS, dengan jeda 


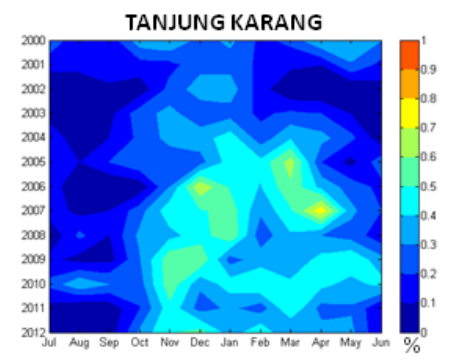

SERANG

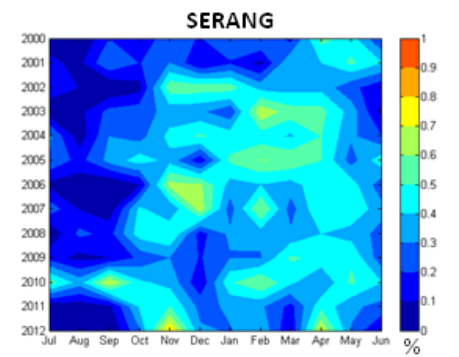

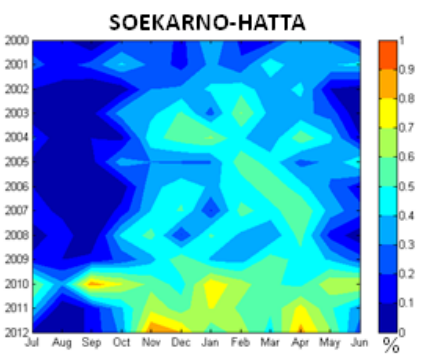

JAKARTA OBSERVATORY

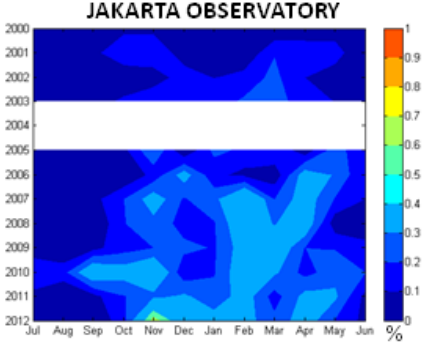

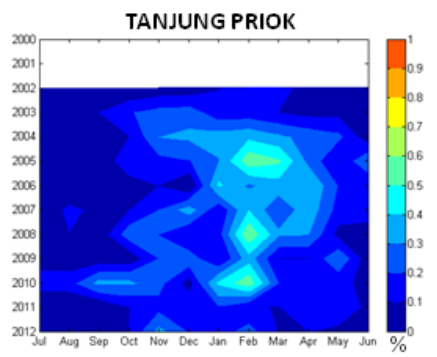

JATIWANGI

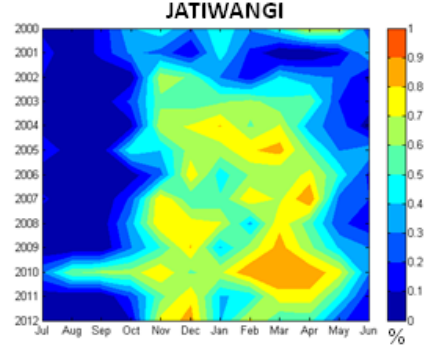

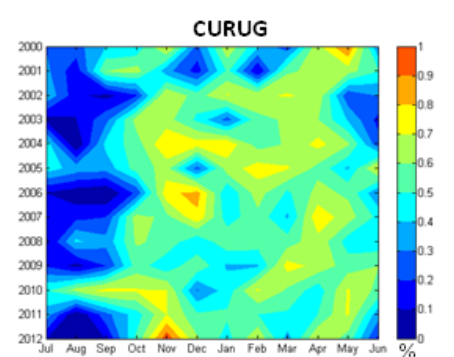

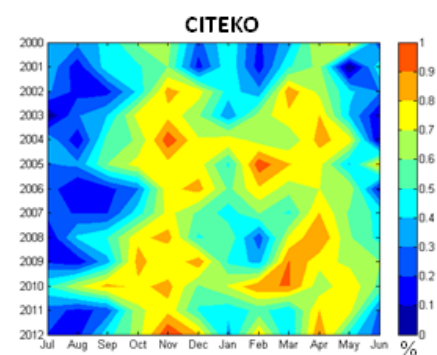

Gambar 4. Grafik distribusi temporal dari frekuensi bulanan TS untuk tiap stasiun di wilayah Jakarta dan sekitarnya. (Bagian kosong pada grafik stasiun Jakarta Observatory dan Tanjung Priok menunjukkan tidak adanya laporan SYNOP pada periode yang bersangkutan)

waktu mencapai 7 sampai 10 jam. Jeda waktu ini diduga terjadi akibat variabilitas musiman curah hujan pada tiap lokasi, seperti yang telah dijelaskan pada sub-bab 3.1.

\subsection{Pengaruh Variabilitas Iklim Global Terhadap Kejadian TS}

Untuk mengetahui pengaruh variabilitas iklim global seperti ENSO dan MJO terhadap kejadian TS di wilayah Jakarta dan sekitarnya, penulis mengelompokkan kejadian TS berdasarkan informasi waktu dari indeks NINO3.4 dan RMM. Khusus untuk MJO, kejadian TS dikelompokkan berdasarkan waktu dari tiap fase MJO yang terjadi pada bulan yang sama dengan informasi pada data SYNOP.

Berdasarkan indeks NINO3.4, tidak terjadi El Nino kuat pada kurun waktu tahun 2000-2012, namun La Nina yang relatif kuat terjadi pada tahun 2010. Gambar 4 menunjukkan diagram distribusi temporal bulanan (bulan vs tahun) dengan kontur warna untuk kejadian TS di setiap lokasi. Dari gambar, terlihat jelas bahwa TS mengalami peningkatan frekuensi kejadian sepanjang tahun 2010 di semua lokasi. Hal ini mengindikasikan bahwa ENSO turut memberikan pengaruh terhadap siklus harian yang merupakan pemicu utama TS di wilayah Jakarta dan sekitarnya.

Gambar 5 menunjukkan grafik anomali kejadian TS pada tiap fase MJO, dibandingkan dengan anomali curah hujan wilayah Jakarta dan sekitarnya pada periode tahun 2000-2012.

Terlihat bahwa fase MJO menyebabkan osilasi yang cukup signifikan pada kejadian TS di tiap lokasi. Peningkatan frekuensi tertinggi hingga mencapai $6 \%$ terjadi pada fase 3 , beberapa saat menjelang MJO melintasi Indonesia bagian barat (fase 4). Periode kering ditandai oleh penurunan frekuensi kejadian TS (fase 5 dan 6), di mana setelahnya, kembali terjadi peningkatan frekuensi TS pada fase 7 dan 8 , walaupun tidak sekuat yang terjadi pada fase 3. Di sisi lain, frekuensi TS relatif tidak mengalami perubahan yang berarti pada fase 1 dan 2. Hal ini menunjukkan bahwa perubahan aktivitas konvektif yang disebabkan MJO ikut mempengaruhi kejadian TS.

Peningkatan distribusi awan Stratiform dan angin zonal pada saat MJO aktif di wilayah Indonesia barat (fase 4) menyebabkan terganggunya aktivitas siklus harian dan menghambat pertumbuhan awan-awan konvektif yang merupakan cikal bakal munculnya TS (Morita et al., 2006). Peningkatan frekuensi TS pada fase 3 dan 7 diduga terjadi akibat adveksi massa uap sebelum dan setelah MJO aktif atau akibat dari Gelombang Rossby. Namun, studi komprehensif dengan menggunakan data spasial resolusi tinggi perlu dilakukan untuk memastikan pengaruh fenomena-fenomena tersebut secara lebih detail. 


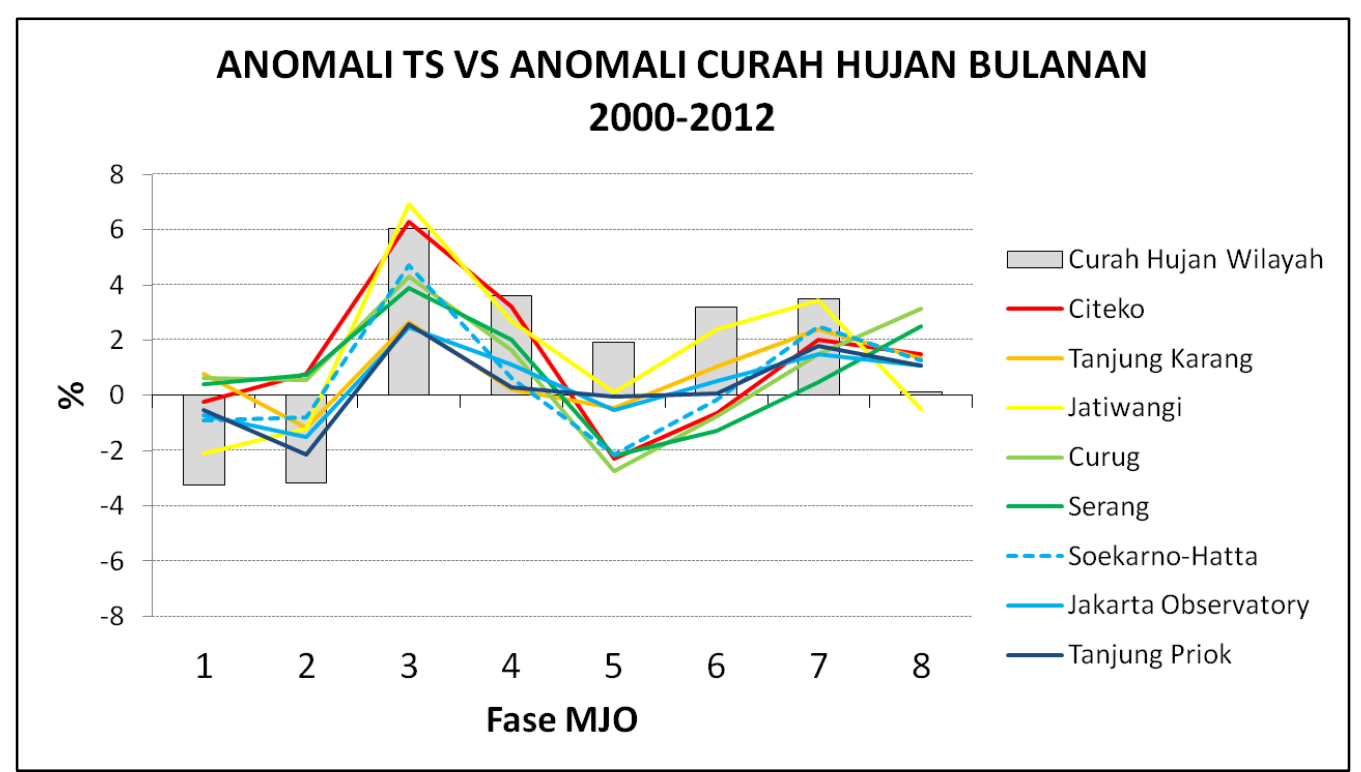

Gambar 5. Grafik anomali kejadian TS bulanan (diagram garis) dan anomali curah hujan wilayah bulanan (diagram batang) dalam persen, pada tiap fase MJO berdasarkan indeks RMM. (Cakupan curah hujan wilayah yang dihitung ditunjukkan oleh kotak dengan garis putus-putus pada Gambar 1)

\section{KESIMPULAN}

Pada studi ini, klimatologi TS di wilayah Jakarta dan sekitarnya dianalisis menggunakan laporan SYNOP per 3 jam dari 8 stasiun cuaca BMKG selama periode tahun 2000-2012 yang kemudian dibandingkan dengan pengamatan curah hujan GSMaP pada periode yang sama.

Dari hasil analisis, diperoleh beberapa poin penting sebagai berikut:

1. Terdapat dua pola klimatologi dominan TS di wilayah Jakarta dan sekitarnya: (1) pola dua periode puncak yang relatif dominan pada daerah-daerah inland atau yang terletak cukup jauh dari teluk Jakarta, dan (2) pola tiga periode puncak pada daerah coastal yang berdekatan dengan teluk Jakarta.

2. TS paling sering terjadi pada periode sesaat sebelum dan sesudah musim hujan (boreal winter), terutama pada bulan November dan April. Khusus pada daerah coastal yang berdekatan dengan teluk Jakarta, puncak kejadian TS juga terjadi pada bulan Februari yang merupakan puncak musim hujan.

3. Frekuensi bulanan kejadian TS tertinggi terjadi di wilayah Citeko dan Curug pada bulan April dan November. Ditinjau dari siklus hariannya, kejadian TS paling sering terjadi pada sore menjelang malam hari, antara pukul 17-19 WIB, terutama di wilayah Citeko.

4. Terdapat jeda waktu yang cukup signifikan antara puncak kejadian TS dan curah hujan maksimum, terutama pada daerah coastal, di mana curah hujan maksimum terjadi hingga 7-10 jam setelah waktu puncak kejadian TS.

5. La Nina kuat pada tahun 2010 memicu peningkatan frekuensi TS di wilayah Jakarta dan sekitarnya sepanjang tahun.

6. Peningkatan frekuensi kejadian TS tertinggi terjadi pada fase 3 dan 7 MJO (berdasarkan indeks RMM). Frekuensi TS cenderung menurun pada saat MJO mulai melintasi Indonesia bagian barat (fase 4) dan mencapai titik minimum pada periode kering (fase 6).

Hasil-hasil di atas menunjukkan bahwa pemicu utama kejadian TS di wilayah Jakarta dan sekitarnya adalah siklus harian (diurnal cycle) akibat konveksi kuat dan pola angin lautdarat (land-sea breeze) yang menyebabkan pertumbuhan awan-awan $\mathrm{Cb}$ pada siang hari di daerah inland, dan bergerak menuju daerah coastal pada sore menjelang malam hari. Proses peluruhan awan $\mathrm{Cb}$ pada saat pergerakannya dari daratan menuju pantai menjelaskan mengapa frekuensi kejadian TS di daerah inland seperti Citeko lebih tinggi dibandingkan dengan daerah coastal seperti Jakarta.

Pada daerah-daerah yang berdekatan dengan Teluk Jakarta, periode puncak kejadian TS pada musim hujan tidak hanya dipacu oleh siklus harian, namun juga dipengaruhi monsun yang mendorong terjadinya seruak dingin (cold surge) dan membawa hujan lebat yang kerap menyebabkan banjir besar pada wilayah-wilayah tersebut. Dari hasil pengolahan data, tampak bahwa efek seruak dingin terhadap kejadian TS semakin berkurang pada daerah-daerah yang cukup jauh dari teluk Jakarta. Hal ini menjelaskan mengapa pada daerah inland, periode puncak kejadian TS tidak terjadi bersamaan dengan puncak musim hujan namun hanya terjadi pada periode peralihan (sebelum dan sesudah musim hujan), di mana pengaruh monsun pada periode tersebut relatif kecil dibandingkan pada periode musim hujan ataupun kemarau.

Selain siklus harian dan monsun, kejadian TS juga mendapat pengaruh yang cukup signifikan dari variabilitas iklim global seperti ENSO dan MJO. La Nina kuat menyebabkan peningkatan frekuensi kejadian TS sepanjang 
tahun 2010 di semua lokasi stasiun pengamatan. Di sisi lain, dinamika atmosfer yang disebabkan oleh MJO turut memiliki peranan penting terhadap frekuensi kejadian TS di wilayah studi. Peningkatan adveksi massa uap air pada saat sebelum dan sesudah MJO melintasi Indonesia bagian barat diduga merupakan salah satu penyebab meningkatnya frekuensi TS pada fase 3 dan 7, sedangkan peningkatan distribusi awan stratiform dan komponen angin zonal pada fase 4 dan 5, serta periode kering pada fase 6, menyebabkan terhambatnya proses konveksi yang merupakan pendorong utama terbentuknya awan-awan $\mathrm{Cb}$, cikal bakal dari TS.

Sebagai penutup, studi ini dilakukan untuk mendorong pemanfaatan data in-situ, khususnya SYNOP, yang walaupun dapat diperoleh secara mudah dan gratis serta mengandung banyak informasi spesifik dari berbagai parameter atmosfer, namun justru relatif jarang digunakan dalam berbagai studi meteorologi di Indonesia. Terlepas dari kehandalan dan kemudahan yang ditawarkannya, penggunaan data SYNOP dalam studi ini memiliki beberapa kekurangan. Salah satu kendala utama adalah terbatasnya distribusi stasiun di wilayah Jakarta dan sekitarnya untuk studi klimatologi. Selain itu, laporan SYNOP sendiri cenderung bias dan subjektif, karena observasi TS hanya dilakukan oleh pengamat stasiun. Dengan demikian, penggunaan data pembanding lain, baik itu data in-situ berbasis instrumen (misalnya Very Low Frequency receiver), maupun data penginderaan jauh (misalnya TRMM) mutlak dilakukan untuk menjamin objektivitas pengamatan TS pada studi-studi berikutnya.

\section{Ucapan Terima Kasih:}

Penulis mengucapkan terima kasih kepada Dr. Shuichi Mori dari Japan Agency and Marineearth Science and Technology (JAMSTEC) untuk bimbingan, komentar dan kritik yang membangun, serta kesempatan untuk mempresentasikan hasil studi ini pada GPM Asia Workshop on Precipitation tahun 2014 dan 2016 di Tokyo.

\section{DAFTAR PUSTAKA}

Chang, C.P., Wang, Z., McBride, J., Liu, C.H. (2005). Annual Cycle of Southeast AsiaMaritime Continent Rainfall and the Asymetric Monsoon Transition. Journal of Climate, 18(2), 287-301. doi: 10.1175/JCLI-3257.1

Christian, H.J., Blakeslee, R.J., Boccippio, D.J., Boeck, W.L., Buechler, D.E., Driscoll, K.T., Goodman, S.J., Hall, J.M., Koshak, W.J., Mach, D.M., Stewart, M.F. (2003). Global Frequency and Distribution of Lightning as Observed from Space by the Optical Transient Detector. Journal of Geophysical
Research, 108(D1), ACL4-1 - ACL4-15. doi: 10.1029/2002JD002347

Hattori, M., Mori, S., Matsumoto, J. (2011). The Cross-Equatorial Northerly Surge over the Maritime Continent and Its Relationship to Precipitation Patterns. Journal of the Meteorological Society of Japan, 89A, 2747. doi: 10.2151/jmsj.2011-A02

Keenan, T., May, P., Holland, G., Rutledge, S., Carbone, R., Wilson, J., Moncrieff, M., Crook, A., Takahashi, T., Tapper, N., Platt, M., Hacker, J., Sekelsky, S., Saito, K., Gage, K. (2000). The Maritime Continent Thunderstorm Experiment (MCTEX): Overview and Some Results. Bulletin of the American Meteorological Society, 81(10), 2433-2455. doi: 10.1175/15200477(2000)081<2433:TMCTEM>2.3.CO;2

Mori, S., Hamada, J-i., Tauhid, Y.I., Yamanaka, M.D., Okamoto, N., Murata, F., Sakurai, N., Hashiguchi, H., Sribimawati, T. (2004). Diurnal Land-Sea Rainfall Peak Migration over Sumatera Island, Indonesian Maritime Continent, Observed by TRMM Satellite and Intensive Rawinsonde Soundings, Monthly Weather Review, 132(8), 20212039. doi: 10.1175/15200493(2004)132<2021:DLRPMO>2.0.CO;2

Mori, S., Hamada, J-I., Sakurai, N., Fudeyasu, H., Kawashima, M., Hashiguchi, H., Syamsudin, F., Arbain, A.A., Sulistyowati, R., Matsumoto, J., Yamanaka, M.D. (2011). Convective System Developed along the Coastline of Sumatera Island, Indonesia, Observed with an X-Band Doppler Radar During the HARIMAU2006 Campaign. Journal of the Meteorological Society of Japan, 89A, 61-81. doi: 10.2151/jmsj.2011-A04

Morita, J., Takayabu, Y.N., Shige, S., Kodama, Y. (2006). Analysis of Rainfall Characteristics of the Madden-Julian Oscillation Using TRMM Satellite Data. Dynamics of Atmospheres Oceans, 42, 107-126. doi: 10.1016/j.dynatmoce.2006.02.002

Neale, R., Slingo, J. (2003). The Maritime Continent and Its Role in the Global Climate: A GCM Study. Journal of Climate, 16(5), 834-848. doi: 10.1175/15200442(2003)016<0834:TMCAIR>2.0.CO;2

Ramage, C.S. (1968). Role of A Tropical "Maritime Continent" in the Atmospheric Circulation. Monthly Weather Review, 96(6), 365-370. doi: 10.1175/15200493(1968)096<0365:ROATMC>2.0.CO;2

Renggono, F., Hashiguchi, H., Fukao, S., Yamanaka, M.D, Ogino, S-Y., Okamoto, N., Murata, F., Sitorus, B.P., Kudsy, M., Kartasasmita, M., Ibrahim, G. (2001). Precipitating Clouds Observed by 1.3-Ghz Boundary Layer Radars in Equatorial Indonesia. Annales Geophysicae, 19(8), 889-897. 
Rodger, C.J., Werner, S., Brundell, J.B., Lay, E.H., Thomson, N.R., Holzworth, R.H., Dowden, R.L. (2006). Detection Efficiency of The VLF World-Wide Lightning Location Network (WWLLN): Initial Case Study. Annales Geophysicae, 24(12), 3197-3124.

Sakurai, N., Murata, F., Yamanaka, M.D., Mori, S., Hamada, J-I., Hashiguchi, H., Tauhid, Y.I., Sribimawati, T., Suhardi, B. (2005). Diurnal Cycle of Cloud System Migration over Sumatera Island. Journal of the Meteorological Society of Japan, 83, 835850. doi: 10.2151/jmsj.83.835

Sakurai, N., Kawashima, M., Fujiyoshi, Y., Hashiguchi, H., Shimomai, T., Mori, S., Hamada, J-I., Murata, F., Yamanaka, M.D., Tauhid, Y.I., Sribimawati, T., Suhardi, B. (2009). Internal Structures of Migratory Cloud Systems with Diurnal Cycle over Sumatera Island During CPEA-I Campaign. Journal of the Meteorological Society of Japan, 87, 157-170. doi: 10.2151/jmsj.87.157

Schumann, U., Huntrieser, H. (2007). The Global Lightning Induced Nitrogen Oxides Source. Atmospherics Chemistry and Physics, 7(14), 3823-3907. doi: 10.5194/acp-73823-2007
Takayabu, Y.N. (2006). Rain-Yield per Flash Calculated from TRMM PR and LIS Data and Its Relationship to The Contribution of Tall Convective Rain. Geophysical Research Letters, 33(18), L18705. doi: 10.1029/2006GL027531

Virts, K. S., Wallace, J.M., Hutchins, M.L., Holzworth, R.H. (2013). Diurnal Lightning Variability over the Maritime Continent: Impact of Low-Level Winds, Cloudiness and the MJO. Journal of the Atmospheric Sciences, 70(10), 3128-3146. doi: 10.1175/JAS-D-13-021.1

Wu, P., Hara, M., Fudeyasu, H., Yamanaka, M.D, Matsumoto, J.,Syamsudin, F., Sulistyowati R., Djajadihardja, Y.S. (2007). The Impact of Trans-equatorial Monsoon Flow on the Formation of Repeated Torrential Rains over Java Island. SOLA, 3, 93-96. doi: 10.2151/sola.2007-024

Wu, P., Arbain, A.A, Mori, S., Hamada, J-i., Hattori, M., Syamsudin, F., Yamanaka, M.D. (2013). The Effects of an Active Phase of the Madden-Julian Oscillation on the Extreme Precipitation Event over Western Java Island in January 2013. SOLA, 9, 79-83. doi: 10.2151/sola.2013018 